\title{
Recent advancements in the functionality of the components from goat milk and its products
}

\author{
Sonam Naagar and SK Kanawjia
}

Received: 07 August 2019 / Accepted: 10 September 2019 / Published online: 28 October 2019

(C) Indian Dairy Association (India) 2019

\begin{abstract}
The purpose of this review is to present inclusive information regarding the recent advancements in the functionality of the components from goat milk and its products. In view of the expected revenues from global goat milk and products touching USD 15 billion in 2024 , there is an urgent need to capitalize on designed fermented dairy products from goats with increased participation of bioactive ingredients in goat milk which in turn lead to excellent biological effects in terms of higher therapeutic and nutritional value. Functional properties enhanced the development of innovative goat dairy products and increased the consumer demand. Goat milk as a potential functional food which is an emerging area for the development of goat milk products by using prebiotics and probiotics. A detailed list of dairy goat milk processors and products commercially available worldwide has also been discussed. The paper suggests that in future the Goat Breeder's Associations need to be established in India on the pattern of US/International Associations to improve the quantity and quality of goat milk for in-depth studies on functionality of the components from goat milk and its products related to medicinal properties of goat milk as therapeutic health food (nutraceutical) and fermented milk beverages/products made with probiotic microflora.
\end{abstract}

Keywords: Bioactive components, Fermented food, Functional, Goat products, Goat, Milk, Prebiotic

\footnotetext{
Dairy Technology Division

ICAR-National Dairy Research Institute, Karnal-132001, Haryana, India

SK Kanawjia( ()

Dairy Technology Division

ICAR-National Dairy Research Institute, Karnal-132001, Haryana, India

Email: skkanawjia@rediffmail.com
}

\section{Introduction}

Goats are termed as "Wet nurse of infants" in the United Kingdom and "Poor man 's cow" in India due to its significant contribution to rural economy. One of the best features of goats is that they are easily adapted into tough weather, which makes them fit for landless and marginal farmers. Goat's contribution is very high in milk and milk products distribution and has major role in rural economy and health (Zenebe et al. 2014). Goat's milk has functional components, such as conjugated linoleic acids; oligosaccharides and bioactive peptides; (Assis et al. 2016; Mukdsi et al. 2013; Kullisaar et al. 2003; Songisepp et al. 2005; Salva et al. 2011).

Goats' milk is rich in protein, calcium, and phosphorus also an appropriate substitute for consumers suffering from cows' milk allergy. Such specialities of goat milk create knowledge of nutrition-health relation and result in the development of the functional food concept.

The share of functional dairy products is $40 \%$ of functional foods which is organized sector in the market by dietary fibres, carotenoids, minerals, fatty acids, prebiotics/probiotics, vitamins and minerals. The foods including enzymes, antioxidants and phytochemicals are also increasing their market share continually (Ortiz et al. 2017). Similarly, functional properties enhanced the development of innovative Goat dairy products and increased the consumer demand (Aguilar-Toalá et al. 2018).

Goat milk as a potential functional food which is an emerging area for the development of goat milk products by using prebiotics and probiotics. Prebiotics are defined as the indigestible food ingredients that promote the growth or activity of beneficial bacteria, thereby benefiting the host. Prebiotics are being added to the food products to stimulate the colonic microflora to get health benefits to the consumers, besides providing textural attributes to the foods (Saad et al. 2013). However, the word probiotic is coined by Kollath (1953) and is derived from the Greek language, which means "for life". Goat milk acts as a main probiotic carrier into humans. These products can be considered as suitable vehicles for delivering probiotics to humans due to their ability in maintaining sufficient probiotic viability during 
shelf life. However, dairy products produced with bovine milk represent the major share of the probiotic market, with only a relatively small number of studies examining functional probiotic goat milk products (Turkmen, et al. 2019). According to Lilly and Stillwell (1965), probiotics are substances produced by microorganisms that promote the growth of other microorganisms. According to FAO/WHO (2001), probiotics are defined as "live microorganisms that, when administered inadequate amounts, confer a health benefit to the host."

The purpose of this review is to present an overall knowledge regarding the recent advancements in the functionality of the components from goat milk and its products. The necessary speculative contexts with some practices on bioactive components in goat milk products have also been discussed. It also summarizes the most recent studies on goat milk and human health and critically, discusses the putative actions of principal goat milk components and goat milk products.

\section{Global market scenario for goat milk and its products}

According to the United Nations' Food and Agriculture Organization (FAO) statistics goat milk as the third most produced variety after bovine milk in the world, (Belewu \& Adewole, 2009). In 2016, there were approximately 1 billion goats worldwide with a milk production of around 15,262 tons (FAO, 2018). India is leading country in goat's milk production followed by Bangladesh and Pakistan in Asia. In Africa, Sudan, South Sudan and Somalia are the major goat milk producers. America is also rising significantly as goat milk producing country (Verruck et al. 2019).

The global goat milk market is estimated to reach revenues of around $\$ 15$ billion by 2024 , growing at a compound annual growth rate of more than 7\% during 2018-2024. Pulina et al. (2018) suggested that in the last decade, goat's milk production increased by more than two-fold and it will increase by another $53 \%$ by 2030. Majority of the goats are used for meat production and a limited proportion is used for milk production. Goat meat (chevon) is one of the most preferred meat types by the consumers in several countries including India. Goat rearing is the second most important activity of livestock sector. There are a total of 102 goat breeds in the world, out of which as many as 28 breeds are found in India (NBAGR, 2018; http://www.nbagr.res.in/reggot. html).

Goat constitutes $26.40 \%$ of the total livestock population in India and the $19^{\text {th }}$ livestock census puts the number of goats in the country at 135.17 million. A decline by $4 \%$ in goat population was noticed from 2007 census to 2012 census. This is certainly not a positive trend, especially in view of the increase in demand for meat as well as milk and due to increase in population and changing pattern of food consumption in favour of protein rich food. The total goat milk production in India is 5.377 million tonnes which is around $3.5 \%$ of the total milk production (155.5million tonnes). The country stands first in goat milk production and its share is $26.31 \%$ in total goat milk production in the world. The global functional dairy beverages market is a very powerful sector of the dairy industry and global dairy-based beverages market is forecasted to reach a market value of 13.9 billion USD by 2021, excluding traditional dairy beverages such as kefir, buttermilk, koumiss, etc (Anonymous, 2018).

\section{Functional properties of goat milk components}

The specific composition of Goat dairy products showed remarkable characteristics in fats, proteins, amino and fatty acids as well as their levels of flavour, taste, aromas and leanness (Goswami et al. 2017). Although goat milk proteins have similarity with major cow milk proteins like á-, â-, ê-caseins, â-lactoglobulin, á-lactalbumin, but differ in genetic polymorphisms (Boyazoglu et al. 2001). Moreover, medium chain fatty acids like caproic, caprylic, capric have been used for the treatment of premature infant nutrition, malabsorption syndromes, gallstone problems, cystic fibrosis intestinal disorders, and coronary diseases because of their unique metabolic ability to provide energy while at the same time lowering, inhibiting and dissolving cholesterol deposits (Ariane et al. 2014). However, the most innovative feature in goat milk fats reported was 18 -carbon fatty acids conjugated linoleic acids (CLA), (Amigo \& Fontecha, 2011). (Bauman et al. 2011) studied health benefits and risk reducing cardiovascular disease by using some CLA isomers (Elwood et al. 2010). In addition, goats' milk has been attributed to individuals suffering from malabsorption syndrome due to therapeutic properties in human nutrition, such as better utilization of fat and mineral salts. Recently, several oligosaccharides have been suggested as potentially bioactive ingredients (Hanson et al. 1961). Oligosaccharides have been proposed as important for child development (Taylor et al. 1986, El-Agamy et al. 2007). Neutral oligosaccharides are vital for the development of the neonates because of their immunomodulating actions (Saini et al. 1991). On the contrary, acidic oligosaccharides help to check the adhesion of pathogens to the intestinal mucosa which help in healthy microbiota (Park et al. 1999, Steger et al. 1960, Wolff et al. 1994). However, goat milk is much richer in lactose-derived oligosaccharides (lactulose, lactitol, lactobionic acid, and galactooligosaccharides), that are beneficial to humans due to their prebiotic and anti-infective features (Turkmen et al. 2017). (Pruksasri \& Supee, 2013) evaluated the feasibility of producing goat milk containing galacto-oligosaccharides (GOS) by treating milk with the enzyme â-galactosidase. The result indicated significant improvements in taste and overall acceptability, high heat stability and shelf life conditions over the acidic conditions of goat milk containing higher GOS concentration. (Silveira et al. 2015) formulated probiotic chocolate beverage with enhanced viscosity and sensory characteristics in which inulin with oligofructose in combination with goat cheese whey was used as functional ingredients. The bifidogenic effect of inulin and fructooligosaccharides, stimulated the intestinal growth of 
bifidobacteria, antagonistically, which suppress other undesirable bacterial growth (Gibson et al. 2017).

Goat milk contains a lower concentration of Potassium, Calcium, Chloride, Phosphorus, Selenium, Zinc and Copper than cow milk (Krstanovic et al. 2010, Lopez-Aliaga et al. 2005). Goat milk has beneficial effects on malabsorption disorders and inflammatory bowel diseases (Geissler et al. 2011). Goat milk improves Zn bioavailability, a mineral with prevented antioxidant capacity (Zago et al. 2001). Zinc shows antioxidant activity. Similarly, selenium as a key mineral for innate and adaptive immunity with B-lymphocytes (B-cells), Natural Killer (NK) cells and Tlymphocytes (T-cells) in goat milk showed immunological properties and acts as a key cofactor for the functioning of the antioxidant enzyme glutathione peroxidase (GPX), which is important for macrophage activation and scavenging harmful free radicals in the body. Goat milk boosted digestibility, due to more zinc, magnesium, alkalinity, iron, and buffering capacity (Pinto et al. 2017). Goat milk plays a key role in all biological reactions and exerts antioxidant and anti-inflammatory effects in the body (Shea et al. 2004, Zenebe et al. 2014). Bergillos-Meca et al. (2015) prepared probiotic fermented milk from concentrated goat milk enriched $\mathrm{Ca}, \mathrm{Mg}, \mathrm{Zn}$ and $\mathrm{P}$ bioavailability (Lactobacillus plantarum C4) using ultrafiltration. (Randheera et al. 2019) reported that Goat's milk comprises higher concentration of vitamin A and whiter in colour than bovine milk (Verruck et al. 2017). Goat milk is also rich in thiamine, riboflavin, niacin, and pantothenate (Turkmen et al. 2017).

\section{Functional properties of goat milk and its products}

Goat milk has stronger flavour and its higher protein content with different phosphates arrangement makes it alkaline in nature (Agnihotri \& Prasad, 1993). Goat milk has smaller size fat globules compared to cow milk which provides a smoother texture. The lower amounts of alphas1-casein present in goat milk results in softer gel products, a higher water holding capacity and a lower viscosity (Gomes et al. 2013). (Tseng et al. 2012) evaluated three types of goat milk viz. full-fat goat milk, low-fat goat milk and skim goat milk. They reported that the colour, 'L' value, 'a' value and ' $b$ ' value of the goat milk decreased with increased milk fat. No significant differences were found in short-chain and middlechain fatty acid (C4-C12), saturated fatty acid (SFA), unsaturated fatty acid (UFA) or the ratio of SFA/UFA among all the three types of milks. Low fat goat milk had the highest appearance score among all the types of milks, whereas the full fat goat milk had higher aroma, flavour, tasty and overall acceptability score than the other groups. (Slacanac et al. 2010) informed significant role of fermented goat milk products in securing food for rural communities by incorporation of live probiotic cells in fermented goat milk represents nutritive and therapeutic properties. Goat milk contains good amount of taurine, which is a final metabolic products of sulphur containing amino acids. It is added to health drink and revitalizers and have several biological functions: regulation of osteoblast metabolism; modulator of growth and of neuronal activity; protection of cells; conjugation of bile salts against various types of injury and prevention of cardiovascular damage; treatment of fatty liver of children and contributed in the treatment of diabetics also.

(Anaeto et al. 2010) studied for the first time a drug called Aimspro made from goat blood improves vision in multiple sclerosis patients and reduce an aspect of disability in the chronic phase of any treatment. Further, goats' milk assured therapeutic properties in malabsorption syndrome by utilization of fat and mineral salts. (Zhang et al. 2015) reported cholesterol-lowering effects and higher antioxidant activity in cultured goat's milk. As a result, of higher proteolytic activity and structural changes in the primary structure of goat's milk in comparison to cow's milk fermented with lactobacilli and bifidobacteria. Prasanna \& Charalampopoulos (2018) showed better performances when Bifidobacterium longum subsp. infantis CCUG 52486 microencapsulated in a variety of matrices: sodium alginate-goat's milk (SAGM), sodium alginate-cow's milk (SACM), sodium alginate (SA) and sodium alginate-casein hydrolysate $(\mathrm{SACH})$ in simulated gastrointestinal conditions. The goat milk is nutritionally and therapeutically healthy and can be used to manufacture a wide variety of products due to its chemical characteristics, including fluid beverage products (low fat/ flavoured/ fortified) and UHT (Ultra High Temperature) milk, fermented products such as cheese, buttermilk/ yogurt, frozen products such as ice cream/ butter, frozen yogurt, condensed/ dried products, sweets and candies (Riberio \& Riberio, 2010). Furthermore, goat milk recently gaining attention in forte products like cosmetic, hair and skincare products. Yet, high quality products can be achieved from fine quality goat milk which has potential to tolerate the technological treatment and be transformed into a product that fulfils the consumer's expectations, in terms of hygiene, nutrition and sensory attributes (Yalinger, 2013).

\section{Fermented goat milk products}

Kullisaar et al. (2003) reported antioxidative and anti-atherogenic effects from fermented goat milk (Lactobacillus fermentus ME3). (Widodo et al. 2010) investigated the quality of fermented goat milk and cow milk, as well as the viability of LAB added with skim milk ( $18 \%$ of solids) using three separately different starters; yoghurt starter (a combination of Streptococcus thermophilus FNCC-0040 and Lactobacillus bulgaricus FNCC-0041), single starter of Lactobacillus acidophilus FNCC-0029 and Lactobacillus casei FNCC-0051. It was, found that $10.83 \%$ decrease in LAB viability in fermented cow milk and $11.40 \%$ in fermented goat milk after 28 days of storage. In conclusion, quality of fermented milk is affected by the starters applied, raw milk source and storage period. (Salva et al. 2011) demonstrated in a mouse immunosuppressant model that Fermented goat milk (Lactobacillus rhamnosus CRL1505) increases the defence 
against intestinal and respiratory infections by stimulating the mucosal immune system. Goat milk yogurt was manufactured from fortified $2 \%$ (wt/vol) skim goat milk powder (SGMP), sodium caseinate $(\mathrm{NaCn})$, whey protein isolate (WPI), whey protein concentrate (WPC), or yogurt texture improver (YTI). "Kishk" is a traditional fermented milk of Lebanon. It is a dried mixture of yogurt and bulghur, prepared from goat milk. (Salameh \& Hosri, 2016). Concentrated yogurt (Labneh) was made from cow and goat's milk and their mixture. Labneh produced from goat's milk has higher ash, moisture and fat content, but lower $\mathrm{pH}$, total solids, protein and lactose content in comparison to the Labneh developed using cow's milk. Labneh with goat's milk had a higher short and medium-chain fatty acid groups (Serhan et al. 2016). Moreno- Montoro et al. (2017) using ultrafiltration process explored various whey fractions from ultrafiltered fermented skimmed goat's milk. (Moreno-Montoro et al. 2018) manufactured highly nutritious novel fermented goat milk which is high in protein and mineral concentration whereas low in lactose and fat content, using probiotic strain Lactobacillus plantarum $\mathrm{C} 4$ in combination with L. bulgaricus and Streptococcus thermophilus. For best viscosity and syneresis a high casein content Ultrafiltration was chosen as the skimmed milk concentration method.

\section{Cheese}

Cheese is a fermented and renowned value added dairy product, which has hundreds of varieties (Pal, 2014). Sheep and goat cheeses are the first choice for connoisseurs as gastronomic and festive products. Goat cheese was invented in Mesopotamia. The milk was probably made into soft cheese, and then hard, ripened goat cheeses were later developed in the Mediterranean basin countries (Jenness, 1980). Yangilar (2013) stated that U.S. Department of Agriculture describes over 400 varieties of goat cheese and lists over 800 names of cheeses, many of which are made from goat milk or combinations of goat with cow, ewe, or buffalo milk. (Slaèanac et al. 2011) reported a higher concentration of $\mathrm{P}, \mathrm{Fe}$, and $\mathrm{Mg}$ in White Slice goat cheese than in White Slice cow cheese. "White Slice" goat cheese is traditional product characteristic for Eastern part of Croatia, as well as for Istria region. "White Slice" goat cheese has been produced on farms and some small cheese factories in East Croatia. (Badriah et al. 2013) prepared a hard cheese like product named as Oggtt which is mainly stable and safe dried fermented milk. It is mainly produced by Bedouins during the spring season when milk is produced in excess amount.

\section{Yoghurt-probiotic dairy-based beverages}

Yogurt, fermented milks (both drinkable and spoonable) has long been associated with longevity and wellbeing of the people (Granato et al. 2010, Özer \& Kirmaci, 2011, Aryana \& Olson, 2017). Conventional yogurt preparations have been in practice by adding value-added ingredients such as probiotics, prebiotics and various plant extracts (Champagne et al. 2018; Fazilah et al. 2018). Probiotic yogurt has reached a great market success during the last two decades or more. Although solid texture, high fat content and $\mathrm{pH}$ values of cheese provide better protection of probiotic cells against undesirable environmental conditions, probiotic cheese market is far below its market potential (Özer \& Kirmaci, 2011).

Probiotic dairy beverages have also long been available in the global beverages markets. Currently, yoghurt is growing in popularity throughout the world, as people are now become aware of health benefits of probiotics in yoghurt. It is a fermented milk product that can be prepared with milk, cream, and skim milk (Pal, 2014). Goat milk yogurt is the richest source of fatty acids, protein, and minerals but due to its typical flavour derived from capric, caprylic, and caproic acids present in this milk and dairy products are not accepted by many consumers (Costa et al.2014). Goat milk yogurt was one of the traditional products from countries where fermented dairy foods originated. Yoghurt manufactured from cows, goats milk $(100 \%, 75 \%, 50 \%$ and $25 \%)$ and their substitution blend exposed the highest protein content $(4.2 \%)$, fat $(4.27 \%)$ and caproic $\left(\mathrm{C}_{6}\right)$, caprylic $\left(\mathrm{C}_{8}\right)$ capric $\left(\mathrm{C}_{10}\right)$ and total solids $(16.22 \%)$ from goat's milk yoghurt (Ehirim \& Onyeneke, 2013). Problems associated with goat milk yogurt manufacturing revealed some quantitative and qualitative properties (Park and Guo, 2006 and Patel \& Roy, 2016). (Bano et al. 2011) manufactured yoghurt with improved sensory scores. Fermentation diminishes the "goaty" flavor, due to yogurt starter cultures. (Damunupola et al. 2014) incorporated beetroot extract at different level in goat milk yogurt to overcome goaty-flavor and goaty-odor. However, beetroot juice addition did not affect the acidity. However, (Costa et al. 2015) proposed to improve the texture of goat's milk yogurt by incorporating of Lactobacillus acidophilus LA-5, inulin and cupuassu pulp. During storage Lactobacillus acidophilus LA-5 viability confer to probiotic physiological benefits which results in higher consistency of yogurts with added inulin at the end of the storage period. So, this strategy could be a technological key for the goat dairy industry (Costa et al. 2015).

\section{Ice-cream and frozen desserts}

Ice-cream is most popular value added dairy product made by freezing pasteurized mix with agitation to incorporate air and get uniform consistency (Pal, 2014). Silva et al. (2016) manufactured goat milk ice cream enriched with different amounts of carob powder. They reported that goat milk ice cream containing carob powder which was added @ 12\% was found to be most acceptable with respect to all sensory attributes. Ranadheera et al. (2013) developed a technology for manufacturing of chocolate flavored probiotic ice cream from goat's milk using probiotic bacterial culture comprising Lactobacillus acidophilus LA-5, Bifidobacterium animalis subsp. lactis BB-12, and novel probiotic Propionibacterium jensenii 702. During manufacturing, freezing process reduces viable cell numbers; however, the 
Table 1 International advanced research on designed fermented goat milk products

\begin{tabular}{|c|c|c|c|}
\hline $\begin{array}{c}\text { Product, Composition \& Starter } \\
\text { culture }\end{array}$ & Functional effects & Conclusions & References \\
\hline $\begin{array}{l}\text { Kefir: Goat milk, Ewe's milk, PUFA } \\
\text { (Maize dried grain with solubles) \& } \\
\text { mixture of mesophilic strains of lactic } \\
\text { acid bacteria, under joint trading code } \\
\text { of } 75106 \text { (Abiasa Inc., Quebec, } \\
\text { Canada) }\end{array}$ & $\begin{array}{l}\text { cis-9,trans-11, and trans-10, cis- } \\
12 \mathrm{C} 18: 2 \text { are two CLA isomers } \\
\text { considered biologically active } \\
\text { agents that have beneficial } \\
\text { effects on human health and are } \\
\text { substrate for the } \\
\text { biohydrogenation process as } \\
\text { well as for de novo synthesis of } \\
\text { fatty acids in the mammary } \\
\text { gland }\end{array}$ & $\begin{array}{l}\text { The highest level of 2, 3-butanedione was } \\
\text { found in goat milk kefir. The increased } \\
\text { content of PUFA level increases kefir } \\
\text { lactase activity only in goat milk kefir, less } \\
\text { prevalent whey aroma, eliminated animal } \\
\text { odor and resultant in a more prominent } \\
\text { cream aroma in ewe milk kefirs, helped to } \\
\text { equal the rate of sheep milk acidification } \\
\text { by increasing the acidification rate in the } \\
\text { initial stage of fermentation. }\end{array}$ & $\begin{array}{l}\text { Cais-so kolinska et al. } \\
2015\end{array}$ \\
\hline
\end{tabular}

Cheese: Goat milk \& Two L. lactis and one Weissella cybaria strains, identified by $16 \mathrm{~S}$ rDNA (primers $27 \mathrm{~F}$ and 1492R)
Fermented goat cheese whey used for the production of substances with bacteriocin-like activity with antilisterial properties and also as a functional ingredient for future application to improve food safety
Fermented milk: Bifidobacterium animalis subsp. lactis Bb-12 (probiotic and Lactobacillus acidophilus Tamr and honey (prebiotic) Pasteurized goat milk, mesophilic culture \& Lactobacillus plantarum 69 Boursin-type cheese: Bifidobacterium animalis subsp.lactisand Lactobacillus rhamnosus Functional foods in

microorganisms able to survive

The viability of $B$. lactis and $L b$.
Goat yogurt may act as inflammatory Bowel disease

High antihypertensive effect i.e lowering blood pressure

Bifidobacterium the passage to the gastrointestinal tract and tolerate acids, bile salts, and gastric enzymes so that they can finally adhere to and colonize the intestinal epithelium
The utilization of whey from the production of goat cheese as a growth medium for L. lactis with highest bacteriocin-like activity obtained, L. lactis were effective against L. monocytogenes. Goat cheese whey used as a low cost culture medium for the production of such antilisterial substances, but studies are required to test the efficacy of this fermented compound as a biopreservative in food models against L. monocytogenes.

Functional product by combining a probiotic goat yogurt with yacon flour and evaluated its maintenance during storage Yacon flour enhanced the number of viable probiotic microorganisms, so it's use as a prebiotic in the food matrix and improved the concentration of fiber in the goat yogurt and the formulation met the standards for the microbiological and physicochemical quality of the final products.

Excellent functional dairy product for small and medium-size dairy industries to enter into functional dairy food market. Goat's milk is widely using as a carrier of probiotic bacteria in the form of stirred yogurt in Arab cultures.

The optimal fermentation conditions were the temperature of $35^{\circ} \mathrm{C}, 0.07 \%$ of $\mathrm{CaCl}_{2}$ and $0.04 \%$ of Tween- 80 . The angiotensinI-converting enzyme-inhibitory activity of the fermented product reach $91.62 \%$ after purification.

Lima et al. 2017

Kinik et al. 2017

Fabersani E. et al. 2018

Goat milk fermented by Lactobacillus plantarum 69 effectively persisted in the gastrointestinal tract and sustained high angiotensin-I-converting enzyme-inhibitory activity. rhamnosus cultures were unaffected throughout 35 days of storage at $4{ }^{\circ} \mathrm{C}$, with a final count of $>7 \log \mathrm{CFU} / \mathrm{g}$. No significant difference was observed between probiotic treatments and control in $\mathrm{pH}$ and titratable acidity. B. animalis presented greater resistance to the artificial gastric and enteric juices than $\mathrm{Lb}$. rhamnosus, with mean decreases in the initial populations of 0.2 and $4.0 \mathrm{log} \mathrm{CFU} / \mathrm{g}$ within 35 days of storage, respectively.
Chen, Zhang, Ji, Shu, \& Chen, 2018

Martins, Deliza, et al. 2018 
viability of all probiotics remained 107 to $108 \mathrm{cfu} \mathrm{g}^{-1}$ up to 52 weeks at $-20^{\circ} \mathrm{C}$ storage. Three types of low-fat soft-serve goat milk ice creams were manufactured using whole milk (3.64\% fat), $2 \%$ fat and skim $(0.71 \%$ fat $)$ goat milk, and evaluated for textural and sensory characteristics of the caprine ice cream products. (McGhee et al. 2015) also manufactured ice creams in which commercial powdered vanilla flavour pre-mix (Alpha Freeze, D466A9047, Tampa, FL, USA) containing $0.25 \%$ fat was incorporated into the three types of goat milk base. The sensory properties were determined at $0,2,4,8$ weeks at $-18^{\circ} \mathrm{C}$ frozen-storage. It was found that the low-fat goat milk ice creams were acceptable even after 8 weeks frozen-storage. (Keily et al. 2016) prepared goat milk frozen yogurt using cajá (Spondiasmombim L.) flavor, a typical fruit of the Brazilian Cerrado with different concentrations of cajá pulp. The sensory evaluation indicated that formulations containing low concentrations of cajá pulp were most acceptable. Goat milk products except pasteurized milk, yoghurt and cheese, are considered to be the dairy products with highest market potential.

\section{International advanced research on designed fermented goat milk Products}

Biada $^{3} \mathrm{a}$ and Konieczny (2018) reviewed many designed fermented dairy beverages with increased participation of bioactive ingredients. Functional components present in milk fat are produced by bio-reacting unsaturated fatty acids in the rumen leads to higher nutritional value (Cieœlak et al. 2009; Szu-macherStrabel, 2011). (Cais-Sokoliñska et al. 2011) studied the effect of oilcake supplemented goat's milk, which results in reduced cholesterol content. Recently, (Niro et al. 2014) partially substituted cow milk with goat or sheep milks to produce acceptable Caciocavallo cheese. From a sensory standpoint, cow Caciocavallo cheeses were characterized by higher scores for sweetness, elasticity, adhesiveness, and humidity (moisture). Mixed cow/sheep cheeses had higher scores for intensity of flavor, acidic, astringent, friability, and salty attributes. In mixed cow/goat cheeses, solubility (fast melt in mouth), intensity of aroma, and bitter attributes predominated (Niro et al. 2014). In Norway, as consumption of the brown whey cheese (Brunost) has decreased, the interest in rennet- and acid-coagulated cheeses has increased (Inglingstad et al. 2014). As a result, the need for higher quality goat milk has increased in recent years. Inglingstad et al. (2014) examined the effect of 2 different hay qualities (low and high quality) and 2 different types of pasture (rangeland and cultivated) on goat milk composition and renneting properties. Milk from pastured goats was superior (higher casein and fat) to that from goats on hay, and goats on cultivated pasture had the highest yield; cultivated pasture yielded milk with higher áS1$\mathrm{CN}$ and ê-CN (better renneting properties) compared with other treatments (Inglingstad et al. 2014). Faccia et al. (2015) reported satisfactory production of Fior di latte cheeses from sheep and goat milk after methodological modifications from the standard cow Fior di latte process. Providing additional support to the findings, Revilla et al. (2016) analyzed the antioxidant capacity of 224 cheese samples in Spain, prepared using mixtures of milk from cows, sheep, and goats, in 2 manufacturing seasons (winter and summer) and over 6 month of ripening. Although animal species was not a significant factor correlated with total antioxidant capacity, statistically significant correlations were found between total antioxidant capacity and season of manufacturing (higher antioxidant activity in summer cheeses), time of ripening, retinol, fat and protein percentages, and some minerals (K, Mg, Na, and P; Revilla et al. 2016). Recently, many studies revealed adequate viability of probiotics in goat's milk products throughout storage period as shown in Table 1.

\section{Conclusions}

The market capacity needs to be opened to developing production and in accordance to the standard of living of the population. Goat farmers must be able to produce milk consistently with local breeds and with good sanitary quality. The dairy goat industry is now significant in India and goat breeder's association need to be established on the pattern of US/International Associations. The goat milk sector is very active with magazines, fairs and innovative products such as new goat cheeses, candy and cosmetic products and this need to be popularized. Goat rearing ensures self-employment and acts as a cushion in distress situations like drought and famine. Medicinal properties of goat milk increased the interest of society to use it as therapeutic health food neutraceutical. Fermented milk beverages made with probiotic microflora showed their documented functional properties, i.e. lactose intolerance, inhibition of pathogenic bacteria development, hypocholesterolemia, normalization of intestinal motility disorders and inhibition of bacterial nitroreductase which catalyses nitrosamines synthesis. To manufacture a product with the desired organoleptic qualities and to preserve the pro-health properties of pro-biotic cultures, they must be carefully selected and cultured. The characteristics that they should have are: moderate acidogenic activity, milk growth ability, antagonism to food spoilage bacteria, and good survival during storage. Moreover, biotechnologists are focusing on designer milk for human health. Promotes and facilitates the development of all segments of the dairy goat industry. Enhancing production and marketing of goat milk products, and promoting research beneficial to member of dairy and food organizations is the need of hour. Increasing the functional properties of goat milk products can also be achieved by using prebiotics, and probiotic bacteria for their production.

\section{References}

Abeijón Mukdsi MC, Haro C, González SN, Medina RB (2013) Functional goat milk cheese with feruloyl esterase activity. J Funct Foods 5: 801-809

Agnihotri MK, Prasad VSS (1993) Biochemical and processing of goat milk and milk products. Small Rumin Res 12: 151-170 
Aguilar-Toalá JE, Garcia-Varela, R, Garcia HS, Mata-Haro V, GonzálezCórdova AF, Vallejo-Cordoba B, Hernández-Mendoza A (2018) Postbiotics: An evolving term within the functional foods Field. Trends Food Sci Tech 75: 105-114

Amigo L, Fontecha J (2011) Encyclopedia of Dairy Sciences Goat Milk. In JW Fuquay, PF Fox, PLH. Mcsweeney 3: 484-493

Anaeto M, Adeyeye GO, Olarinmoye C, Tayo GO (2010) Goat products: meeting the challenges of human health and nutrition. ABJNA 1: 1231-136

Annual Report (Central Institute for Research on Goats) 2018

Anonymous(2018)ht2tps://www.businesswire.com/news/home/ 20160715005488/en/Global-Dairy-Based-Beverages-MarketWorth-USD

Ariane V, Rahmann G, Knaus W (2014) Fatty acid composition of goat milk produced under different feeding regimens and the impact on Goat Cheese. Agri Sci 12: 161-166.

Aryana K J, Olson D W (2017) A 100-Year Review: Yogurt and other cultured dairy products. J Dairy Sci 100: 9987-10013

Assis POA de, Guerra GCB, Araújo DF de S, Araújo Júnior R F de, Machado TADG, Araújo AA de, Queiroga, R de C R do E (2016) Intestinal anti-inflammatory activity of goat milk and goat yoghurt in the acetic acid model of rat colitis. Int Dairy J 56: 45-54

Martins BA, Deliza R, Santos dos KMO, Walter EHM, Martins JM, Rosenthal A (2018) Viability of Probiotics in Goat Cheese during Storage and under Simulated Gastrointestinal Conditions. Food Bioprocess Tech 11: 853-863

Badriah O, Al-Abdulkarim, Maha SO, Muna ALEl-N (2013) Determination of chemical composition and storage on dried fermented goat milk product (Oggtt). J Sau Soc Agri Sci 12: 161-166

Bano P, Abdullah M, Nadeem M, Babar M, Khan GA (2011) Preparation of functional yoghurt from sheep and goat milk blends. Pak J Agric Sci 48: 211-215

Bauman DE, Tyburczy C, O’Donnell AM, Lock A L (2011) Encyclopedia of dairy sciences. Milk lipids: Conjugated linoleic acid 3:660-664 London UK: Elsevier Ltd.

Belewu MA, Adewole AM (2009) Goat milk a feasible dietary based approach to improve the nutrition of orphan and vulnerable children. Pak J Nutr 8: 1711-1714

Bergillos-Meca T, Cabrera-Vique C, Artacho R, Moreno-Montoro M, Navarro-Alarcon M, Olalla M, Ruiz-Lopez MD (2015) Does Lactobacillus plantarum or ultrafiltration process improve $\mathrm{Ca}, \mathrm{Mg}$, $\mathrm{Zn}$ and $\mathrm{P}$ bioavailability from fermented goats' milk. Food Chem 187: $314-321$

Biada ${ }^{3}$ A A, Konieczny P (2018) Goat's milk-derived bioactive components. Mljekarstvo 68: 239-253

Boyazoglu J, Morand-Fehr P (2001) Mediterranean dairy sheep and goat products and their quality A critical review. J Small Rumin Res 40: 111

Ranadheera CS, Evans CA, Baines SK, Balthazar CF, Cruz AG, Esmerino EA, Freitas MQ, Pimentel TC, Wittwer AE, Naumovski N, Juliana SG, Sant'Ana AS, Ajlouni S, Vasiljevic T (2019) Probiotics in Goat Milk Products: Delivery Capacity and Ability to Improve Sensory Attributes. Comprehensive Rev Food Sci Food Saf 00: 1-16

Cais-Sokoliñska D, Majcher M, Pikul J, Bieliñska S, Czauderna S, Wójtowski $\mathrm{J}$ (2011) The effect of Camelina sativa cake diet supplementation on sensory and volatile profiles of ewe's milk. Afr J Biotechnol 10: $7245-7252$

Cais-Sokolinska D, Wojtowski J, Pikul J, Lasik-Kurdys M (2017) Analysis of metabolic activity of lactic acid bacteria and yeast in model kefirs made from goat's milk and mixtures of goat's milk with mare's milk based on changes in electrical conductivity and impedance. Mljekarstvo 67: 277-282
Cais-Sokolinska D, Wojtowski J, Pikul J, Dankow R, Majcher M, Teichert J, Bagnicka E (2015) Formation of volatile compounds in kefir made of goat and sheep milk with high polyunsaturated fatty acid content. J Dairy Sci 98: 6692-6705

Champagne CP, Cruz GA, Daga M (2018) Strategies to improve the functionality of probiotics in supplements and foods. Curr Opin Food Sci 22: 160-166

Chen L, Zhang Q, Ji Z, Shu G, Chen H (2018) Production and fermentation characteristics of angiotensin-I-converting enzyme inhibitory peptides of goat milk fermented by a novel wild Lactobacillus plantarum 69. LWT-Food Sci Tech 91: 532-540.

Cieœlak A, Machmüller A, Szumacher-Strabel M, Scheeder MRL (2009) A note on the comparison of two extraction methods used to quantify C18 fatty acids in feed and digest of ruminants. J Anim Feed Sci 18: 362-367 https://doi.org/10.22358/jafs/66400/2009

Clark S \& García MB (2017) a 100-year review: Advances in goat milk research. J Dairy Sci 100: 10026-10044

Costa MP, Balthazar CF, Franco RM, Mársico ET, Cruz AG, Conte Junior CA (2014) Changes on expected taste perception of probiotic and conventional yogurts made from goat milk after rapidly repeated exposure. J Dairy Sci 97: 2610-2618

Costa MP, Frasao BS, Silva ACO, Freitas MQ, Franco RM, Conte-Junior C (2015). Cupuassu (Theobroma grandiflorum) pulp, probiotic, and prebiotic: Influence on color, apparent viscosity, and texture of goat milk yogurts. J Dairy Sci 98: 5995-6003

Damunupola DAPR, Weerathilake WADV, Sumanasekara GS (2014) Evaluation of Quality Characteristics of Goat Milk Yogurt Incorporated with Beetroot Juice. Int J Scientific Res Publi 4: 1-5

de Vrese M, Schrezenmeir J (2008) Probiotics, prebiotics, and synbiotics. Adv Biochem Eng Biotech 111: 1-66

Ehirim FN, Onyeneke EN (2013) Physico-chemical and organoleptic properties of yoghurt manufactured with cow milk and goat milk. Acad Res Int 4: 245-252

El-Agamy E I (2007) The challenge of cow milk protein allergy. Small Rumin Res 68: 64-72

Elwood PC, Pickering JE, Givens D, Gallacher JE (2010) The consumption of milk and dairy foods and the incidence of vascular disease and diabetes An overview of the evidence. Lipids 45: 925-939

Fabersani E, Grande MV, Coll Aráoz MV, Zannier M L, Sánchez SS, Grau A, Honoré SM (2018) Metabolic effects of goat milk yogurt supplemented with yacon flour in rats on high-fat diet. J Func Foods 49: 447-457.

Faccia MA, Trani G, Gambacorta P, Loizzo A, Cassone, Caponio F (2015) Production technology and characterization of Fior di latte cheeses made from sheep and goat milks. J Dairy Sci 98: 1402-1410

FAO/WHO. (2001) Report of a Joint FAO/WHO Expert Consultation on evaluation of health and nutritional properties of probiotics in food including powder milk with live LAB. Food and Agriculture Organization of the United Nations World Health organization

FAOstat. (2018) Food and Agriculture Organization of the United Nations database http://faostat3.fao.org/home/E

Fazilah N F, Ariff AB, Khayat ME, Rios-Solis L \& Halim M (2018) Influence of probiotics, prebiotics, synbiotics and bioactive phytochemicals on the formulation of functional yogurt. J Func Foods 48: 387-399.

Geissler CH Powers, 2011. Human Nutrition London, UK Churchill Livingstone. 509-532.

Gibson GR, Hutkins R, Sanders ME, Prescott SL, Reimer RA, Salminen SJ, Reid G (2017) The International Scientific Association for Probiotics and Prebiotics (ISAPP) consensus statement on the definition and scope of prebiotics. Nat Rev Gastro Hepat 14: 491-502

Gomes JJL, Duarte AM, Batista ASM, Figueiredo RMF, Sousa EP, Souza EL, Queiroga RC (2013) Physicochemical and sensory properties 
of fermented dairy beverages made with goat's milk, cow's milk and a mixture of the two milks. Food Sci Technol 54: 18-24

Goswami M, Bharti SK, Tewari A, Sharma H, Karunakara KN, Khanam T (2017) Implication of functional ingredients of goat milk to develop functional foods. J Anim Feed Sci Technol 5: 65-72

Granato D, Branco GF, Cruz AG, Faria J, de AF, Shah NP (2010) Probiotic dairy products as functional foods. Compr Rev Food Sci 9: 455-470

Hanson LA -Mansson I (1961) Immune electrophoretic studies of bovine milk and milk products. Acta Paediatr 50: 484-490

Inglingstad RA, Steinshamn H, Dagnachew BS, Valenti B, Criscione A, Rukke EO, Devold TG, Skeie SB and Vegarud GE 2014 Grazing season and forage type influence goat milk composition and rennet coagulation properties. J Dairy Sci 97: 3800-3814

Ismail M, Hamad M, Elraghy EM (2018) Quality of Rayeb milk fortified with Tamr and honey. Br Food J 120: 499-514

Jenness R (1980) Composition and characteristics of goat milk review. J Dairy Sci 63: 1605-1630

Keily AMO, Luciana SR, Glauco VO, Cristina TRV 2016 Goat Milk Frozen Yogurt Cajá (Spondiasmombin L.) Flavor: Development and Sensory Acceptance of an Exotic Food. Curr Nutr Food Sci 12: 105-112

Kinik O, Kesenkas H, Ergonul PG, Akan E, Kýnýk Ö, Kesenka ${ }^{\circ}$ H, Akan E (2017) The effect of using pro and prebiotics on the aromatic compounds, textural and sensorial properties of synbiotic goat cheese. Mljekarstvo 67: 71-85

Kollath W (1953) Nutrition and the tooth system general review with special reference to vitamins. Dtsch Zahnärztl Z 8: 7-16

Krstanovic, Slacanac VV, Bozanic R, Hardi J, Rezessyne J, Lucan M (2010) Nutritional and therapeutic value of fermented caprine milk. Int $\mathbf{J}$ Dairy Tech 63: 171-189

Kullisaar T, Songisepp E, Mikelsaar M, Zilmer K, Vihalemm T, Zilmer M (2003) Antioxidative probiotic fermented goats' milk decreases oxidative stress-mediated atherogenicity in human subjects. Brit $\mathrm{J}$ Nutr 90: 449-456

Kullisaar T, Songisepp E, Mikelsaar M, Zilmer K, Vihalemm T, Zilmer M (2003) Antioxidative probiotic fermented goat's milk decreases oxidative stress mediated, Atherogenicity in human subjects. Br J Nutr 90: 449-456

Lilly DM, Stillwell RH (1965) Probiotics growth-promoting factors produced by microorganisms. Sci 147: 747-748

Lima EL, Fernandes J, Cardarelli HR, Lima EDC, Fernandes JD, Cardarelli HR (2017) Optimized fermentation of goat cheese whey with Lactococcus lactis for production of antilisterial bacteriocin-like substances. LWT-Food Sci Tech 84: 710-716

Lopez-Aliaga I, Alferez MJ, Nestares MT, Ros PB, Barrionuevo M, Campos MS (2005) Goat milk feeding causes an increase in biliary secretion of cholesterol and a decrease in plasma cholesterol levels in rats. $\mathrm{J}$ Dairy Sci 88: 102-141

McGhee CE, Jones JO, Park YW (2015) Evaluation of textural and sensory characteristics of three types of low-fat goat milk ice cream. Small Rumin Res 123: 293-300.

Moreno-Montoro M, Navarro-Alarcón M, Bergillos-Meca T, GiménezMartínez R, Sánchez-Hernández S, Olalla-Herrera M (2018) Physicochemical, Nutritional, and Organoleptic Characterization of a Skimmed Goat Milk Fermented with the Probiotic Strain Lactobacillus plantarum C4. Nutrients 10:633

Moreno-Montoro M, Olalla-Herrera M, Rufian-Henares JA, Martinez RG, Miralles B, Bergillos T, Jauregi P (2017) Antioxidant, ACE-inhibitory and antimicrobial activity of fermented goat milk: Activity and physicochemical property relationship of the peptide components. Food Func 8: 2783-2791

NBAGR (2018)http://www.nbagr.res.in/reggot.html.
Niro S, Fratianni A, Tremont P, Sorrentino E, Tipaldi L, Panfili G Coppola R (2014) Innovative Caciocavallo cheeses made from a mixture of cow milk with ewe or goat milk. J Dairy Sci 97: 1296

Ortiz Y, García-Amézquita E, Acosta CH, Sepúlveda DR (2017) Functional dairy products. Global food security and wellness 67-103

Özer B, Kirmaci HA (2011) Technological and health aspects of probiotic cheese. Cheese types, nutrition and consumption1-42

Pal M (2014) Goat milk and its potential in dairy industry. Addis Ababa University, College of Veterinary Medicine (1-11) MSc Lecture Notes Debre Zeit, Ethiopia.

Park YW, Guo M (2006) Handbook of milk of non-bovine mammals Haenlein Blackwell Oxford: 59-106. https://doi.org/10.1002/ 9780470999738.ch4

Patel AS, Roy SK (2016) Comparative rheological study of goat milk yoghurt and cow milk yoghurt. Indian J Dairy Sci 69: 124-127

Pinto JMS (2017) Effect of probiotic co-cultures on physicochemical and biochemical properties of small ruminants' fermented milk. Int Dairy J 72: 29-35

Prasanna PHP, Charalampopoulos D (2018) Encapsulation of Bifidobacterium longum in alginate-dairy matrices and survival in simulated gastrointestinal conditions, refrigeration, cow milk and goat milk. Food Biosci 21: 72-79.

Pulina G, Milán MJ, Lavín MP, Theodoridis A, Morin E, Capote J, Caja G (2018) Invited review: Current production trends, farm structures, and economics of the dairy sheep and goat sectors. J Dairy Sci 10: 6715-6729

Ranadheera CS, Evans CA, Adams MC, Baines SK (2013) Production of probiotic ice cream from goat's milk and effect of packaging materials on product quality. Small Ruminant Res 112: 174-180

Revilla I, MI Gonzalez-Martin AM, Vivar-Quintana MA, Blanco-Lopez IA, Lobos-Ortega, JM Hernandez-Hierro (2016) Antioxidant capacity of different cheeses: Affecting factors and prediction by near infrared spectroscopy. J Dairy Sci 99: 5074-5082

Ribeiro AC, Ribeiro, SDA (2010) Speciality products made from goat milk. Small Rumin Res 89: 225-233

Saad N, Delattre C, Urdaci M, Schmitter JM, Bressollier P (2013) An overview of the last advances in probiotic and prebiotic field. LWT Food Sci Tech 50: 1-16

Saini AL, Gill RS (1991) Goat milk: An attractive alternate. Indian Dairyman 42: 562-564.

Salameh C, Hosri C (2016) Evaluation of the hygienic quality and nutritional value of traditional Lebanese "Kishk", a dried fermented goat milk product. Options Méditerranéennes Série A, Séminaires Méditerranéens 115: 169-173

Salva S, Nunez M, Villena J, Ramon A, Font G, Alvarez S (2011) Development of a fermented goats' milk containing Lactobacillus rhamnosus: in-vivo study of health benefits. J Sci Food Agric 91: 2355-2362

Sanna MG, Mangia NP, Garau G, Murgia MA, Massa T, Franco A, Deiana P, (2005) Selection of folate-producing lactic acid bacteria for improving fermented goat milk. Ital J Food Sci 17: 143-154

Shea O, Bassaganya M, Riera J ICM Mohede, (2004) Immunomodulatory properties of conjugated linoleic acid. Am Soc Clin Nutr 79: 11991206

Silva ACC, Silva IPO, Messias CMB, Mendes MLM (2016) Development and acceptance of ice cream and goat milk enriched with carob. Hygiene Alimentairus 30: 258-259

Silvani Verrucka, Adriana Dantasb, Elane Schwinden Prudencio (2019) Functionality of the components from goat's milk, recent advances for functional dairy products development and its implications on human health. J Func Foods 52: 243-257

Silveira EO, Lopes Neto JH, Silva LA, Raposo AES, Magnani M, Cardarelli HR (2015) The effects of inulin combined with oligofructose and 
goat cheese whey on the physicochemical properties and sensory acceptance of a probiotic chocolate goat dairy beverage. LWT Food Sci Tech 62: 445-451

Slacanac V, Bozanic R, Hardi J, Rezessyne Szabo J, Lucan M, Krstanovic V (2010) Nutritional and therapeutic value of fermented caprine milk. Int J Dairy Tech 63: 171-189

Slaèanac V, Hardi J, Luèan M, Komleniæ DK, Krstanoviæ V Jukiæ M (2011) Concentration of nutritional important minerals in Croatian goat and cow milk and some dairy products made of these Croat. J Food Sci Technol 3: 21-25

Songisepp E, Kals J, Kullisaar T, Mändar R, Hütt P, Zilmer M, Mikelsaar $M$ (2005) Evaluation of the functional efficacy of an antioxidative probiotic in healthy volunteers. Nutr J 4: 22

Steger H (1960) Uber den cholesteringehalt der milch unserer haustiere im verlaufe der laktation und dessen bestimmung (content of cholesterol in milk of domestic animals during lactation and determination methods). Arch. Tierzucht 4: 199

Szumacher-Strabel M, Cieœlak A, Zmora P, Pers-Kamczyc E, Bieliñska S, Stanisz M, Wójtowski J (2011) Camelina sativa cake improved unsaturated fatty acids in ewe's milk. J Sci Food Agric 91: 20312037

Taylor SL (1986) Immunologic and allergic properties of cow's milk proteins in humans. J Food Protect 49: 239-250

Tilahun Zenebe, Nejash Ahmed, Tadele Kabeta Girma Kebede (2014) Review on Medicinal and Nutritional Values of Goat Milk. Acad J Nutr 3: 30-39
Tseng T, Masuda J, Tsui Y Wen Shyan C (2012) Physicochemical, microbiological and sensory analysis of full-fat, low-fat and skim goat milk. J Chin Soc Anim Sci 41: 101-109

Turkmen N (2017) The nutritional value and health benefits of goat milk components. Nutrients in dairy and their implications on health and disease 441-449 Preedy Cambridge, MA: Academic Press

Turkmen N, Akal C, O” zer B (2019) Probiotic dairy-based beverages a review. J Func Foods 53: 62-75

Widodo, Taufiq TT, Nosa Septiana Anindita (2013) Fermented Goat Milk and Cow Milk Produced by Different Starters of Lactic Acid Bacteria, Quality Studies. J Agric Sci Technol 3: 904-911

Wolff RL (1994) Contribution of trans-18:1 acids from dairy fat to European diets. J Am Oil Chem Soc 71: 227-283

Yangilar F (2013) As a potentially functional food: goat's milk and products. J Food Nutr Res 1: 68-81

Zago MP, PI Oteiza (2001) The antioxidant properties of zinc: interactions with iron and antioxidants. Free Radical Bio Med 31: 266-274.

Zhang WQ, Ge WP, Yang J, Xue XC, Wu SZ, Chen Y, Qin LH (2015) Comparative of in vitro antioxidant and cholesterol-lowering activities of fermented goat \& cow milk. Resources Environ Eng 417-424 